\title{
The Arab region's contribution to global COVID-19 research: Bibliometric and visualization analysis
}

\author{
Sa'ed H. Zyoud ${ }^{1,2}$ (D)
}

\begin{abstract}
Background: At the global level and in the Arab world, particularly in low-income countries, COVID-19 remains a major public health issue. As demonstrated by an incredible number of COVID-19-related publications, the research science community responded rapidly. Therefore, this study was intended to assess the growing contribution of the Arab world to global research on COVID-19.
\end{abstract}

Methods: For the period between December 2019 and March 2021, the search for publications was conducted via the Scopus database using terms linked to COVID-19. VOSviewer 1.6.16 software was applied to generate a network map to assess hot topics in this area and determine the collaboration patterns between different countries. Furthermore, the research output of Arab countries was adjusted in relation to population size and gross domestic product (GDP).

Results: A total of 143,975 publications reflecting the global overall COVID-19 research output were retrieved. By restricting analysis to the publications published by the Arab countries, the research production was 6131 documents, representing 4.26\% of the global research output regarding COVID-19. Of all these publications, 3990 (65.08\%) were original journal articles, 980 (15.98\%) were review articles, 514 (8.38\%) were letters and 647 (10.55\%) were others, such as editorials or notes. The highest number of COVID-19 publications was published by Saudi Arabia $(n=2186,35.65 \%)$, followed by Egypt $(n=1281,20.78 \%)$ and the United Arab Emirates (UAE), $(n=719$, 11.73\%). After standardization by population size and GDP, Saudi Arabia, UAE and Lebanon had the highest publication productivity. The collaborations were mostly with researchers from the United States $(n=968)$, followed by the United Kingdom $(n=661)$. The main research lines identified in COVID-19 from the Arab world are related to: public health and epidemiology; immunological and pharmaceutical research; signs, symptoms and clinical diagnosis; and virus detection.

Conclusions: A novel analysis of the latest Arab COVID-19-related studies is discussed in the current study and how these findings are connected to global production. Continuing and improving future collaboration between developing and developed countries will also help to facilitate the sharing of responsibilities for COVID-19 in research results and the implementation of policies for COVID-19.

Keywords: Arab world, Bibliometric, COVID-19, Novel coronavirus, Scopus

\footnotetext{
Correspondence: saedzyoud@yahoo.com; saedzyoud@najah.edu

'Department of Clinical and Community Pharmacy, College of Medicine and

Health Sciences, An-Najah National University, Nablus 44839, Palestine

${ }^{2}$ Clinical Research Centre, An-Najah National University Hospital, Nablus

44839, Palestine
}

C C The Author(s). 2021 Open Access This article is licensed under a Creative Commons Attribution 4.0 International License, which permits use, sharing, adaptation, distribution and reproduction in any medium or format, as long as you give appropriate credit to the original author(s) and the source, provide a link to the Creative Commons licence, and indicate if changes were made. The images or other third party material in this article are included in the article's Creative Commons licence, unless indicated otherwise in a credit line to the material. If material is not included in the article's Creative Commons licence and your intended use is not permitted by statutory regulation or exceeds the permitted use, you will need to obtain permission directly from the copyright holder. To view a copy of this licence, visit http://creativecommons.org/licenses/by/4.0/. The Creative Commons Public Domain Dedication waiver (http://creativecommons.org/publicdomain/zero/1.0/) applies to the data made available in this article, unless otherwise stated in a credit line to the data. 


\section{Background}

Coronavirus disease 2019 (COVID-19) first came to light in December 2019 with the appearance of viral pneumonia cases in Wuhan City, Hubei Province, China $[1,2]$. COVID-19 has produced heavy burdens and brought enormous global public health challenges. In the first 6 months of the pandemic, the novel coronavirus caused more than 1 million deaths and enormous economic and social upheavals worldwide [3, 4]. The World Health Organization (WHO) declared the COVID-19 outbreak a Public Health Emergency of International Significance on 30 January 2020 and described the COVID-19 epidemic as a pandemic 6 weeks later.

As of 9 March 2021, more than 116.5 million cases of COVID-19 and more than 2.5 million deaths from the disease have been reported worldwide [5]. A study conducted by Al-Kindi indicated that the rate of COVID-19 infection is higher in the most populated areas [6]. COVID-19 has a high death rate in hospitalized patients due to respiratory failure, with certain patients needing mechanical ventilation [7]. Some drugs have been available, including antimalarials (e.g. chloroquine), antivirals (e.g. lopinavir/ritonavir, remdesivir), anti-inflammatories (e.g. dexamethasone) and monoclonal antibodies (e.g. tocilizumab) but their actual effect on the course of the infection was obscure at the start of the pandemic [8].

The emerging global threat of COVID-19 has contributed to an explosion of publications on coronaviruses. COVID-19-related publications have been published increasingly and the findings of scientific studies are continuously emerging with the collaborative efforts of researchers and clinicians around the world [9-14]. As of 8 March 2021, 110,839 published articles on COVID19 were included in PubMed [15].

As the number of scientific publications rapidly increases, it is important to dissect the variables that lead to highly impactful publications. Bibliometrics, along with visualization techniques, have been reported to be helpful in evaluating research output for emerging infectious disease outbreaks [16-24].

It can be seen that the existing literature has revealed some important issues in the field of COVID-19, such as important documents, co-citation networks [10-12, 2532] and the development status of COVID-19 in a specific field, such as COVID-19 in the environment [33], registered clinical trials on the COVID-19 pandemic [13], traditional Chinese medicine for COVID-19 [34] and business and management during the COVID-19 pandemic [35]. Previous publications on COVID-19 primarily evaluated international studies' research performance and paid less attention to the research framework of COVID-19 in the Arab world. In other words, in the Arab world there is a lack of bibliometric studies on COVID-19 investigating the research performance in a quantitative method, and the connection between hot research topics has not been clearly disclosed. Therefore, the aim of this analysis was to assess the volume and impact of the Arab scientific output among the COVID-19 publications indexed in Scopus. Consequently, this study's main subject is the collaboration network, along with existing research topics and hotspots that need to be further studied. The findings could help to identify more effective approaches to future research in the funding, planning, implementation and networking of quality and sustainability-based research.

\section{Methods}

All publications indexed in Scopus as COVID-19 were downloaded and analysed by bibliometric methods. The Scopus database offers a wider range of journals compared to PubMed and Web of Science [36]. Furthermore, it has more non-English scientific journals than Web of Science, which is important because no language restriction was applied in the current research. The Scopus database provides comprehensive, multidisciplinary citation data and is considered one of the primary data sources for bibliometric analysis [36-38]. In addition, Scopus data can be easily exported to Microsoft Excel or third-party software such as VOSviewer for further analysis and mapping.

The search took place in March 2021 and all publications published before 8 March 2019 were evaluated. The finalized search string with COVID-19 primary emphasis and keywords used in the TITLE-ABSTRACTKEYWORDS fields [11, 25, 32, 39, 40] is as follows: "coronavirus 2019" or "COVID 19" or "coronavirus disease 2019" or "2019 novel coronavirus" or "2019-novel CoV" or "COVID 2019" or "2019 ncov" or "COVID19" or "nCoV-2019" or "nCoV2019" or "nCoV 2019" or "COVID-19" or "Severe acute respiratory syndrome coronavirus 2" or "2019-ncov" or "SARS-CoV-2". All 22 Arab countries [41] were used as country keys in this study, accompanied by terms related to COVID-19 (Table 1).

The bibliometric parameters used to analyse the publications related to COVID-19 from Arab countries were: type of documents, publication output, journals, country and institutions, publication patterns, citation patterns and collaboration analysis. Furthermore, the research output of Arab countries was adjusted by using the adjustment index (AI) formula in relation to population size and gross domestic product (GDP) in 2019 [42]. The following formula was used to calculate the AI [43-45]: AI $=$ [Total number of publications for the country / GDP per capita of the country] $\times 1000$, where GDP per capita is the country's GDP divided by its population. 
Table 1 Ranking and contribution of Arab countries in research on COVID-19

\begin{tabular}{|c|c|c|c|c|c|c|c|}
\hline Rank & Country & Number of publication & $\%$ & Population by milliun & GDP by billion & Al & Al Rank \\
\hline $1 s t$ & Saudi Arabia & 2186 & 35.65 & 35 & 800 & 49.97 & $1 s t$ \\
\hline 2nd & Egypt & 1281 & 20.89 & 100 & 350 & 4.48 & 6th \\
\hline $3 r d$ & UAE & 719 & 11.73 & 10 & 450 & 32.36 & 2nd \\
\hline 4th & Morocco & 431 & 7.03 & 35 & 120 & 1.48 & 9th \\
\hline 5 th & Jordan & 430 & 7.01 & 10 & 45 & 1.94 & 8th \\
\hline 6th & Qatar & 402 & 6.56 & 3 & 220 & 9.19 & 5 th \\
\hline 7th & Iraq & 357 & 5.82 & 40 & 250 & 1.25 & 11th \\
\hline 8th & Lebanon & 347 & 5.66 & 7 & 55 & 15.62 & $3 r d$ \\
\hline 9th & Tunisia & 222 & 3.62 & 12 & 50 & 0.76 & 16 \\
\hline 10th & Oman & 205 & 3.34 & 5 & 80 & 0.92 & 12 th \\
\hline 11th & Kuwait & 203 & 3.31 & 4 & 180 & 14.89 & 4th \\
\hline 12 th & Algeria & 135 & 2.20 & 45 & 220 & 0.84 & 15th \\
\hline 13th & Bahrain & 110 & 1.79 & 1.6 & 35 & 0.86 & 14th \\
\hline 14 th & Sudan & 101 & 1.65 & 40 & 80 & 0.42 & 17 th \\
\hline 15th & Palestine & 86 & 1.40 & 4.5 & 16 & 1.38 & 10th \\
\hline 15th & Yemen & 86 & 1.40 & 30 & 40 & 3.87 & 7 th \\
\hline 17th & LAJ & 57 & 0.93 & 7 & 80 & 0.28 & 18th \\
\hline 18th & SAR & 42 & 0.69 & 22 & 40 & 0.92 & 13th \\
\hline 19th & Somalia & 14 & 0.23 & 14 & 1.1 & 0.03 & 20th \\
\hline 20th & Mauritania & 10 & 0.16 & 4.5 & 8 & 0.04 & 19th \\
\hline $21 \mathrm{st}$ & Comoros & 2 & 0.03 & 0.8 & 1.2 & 0.00 & 22nd \\
\hline $21 \mathrm{st}$ & Djibouti & 2 & 0.03 & 0.9 & 3.5 & 0.02 & $21 s t$ \\
\hline
\end{tabular}

Abriviations: Al adjustment index, GDP gross domestic product, LAJ Libyan Arab Jamahiriya, SAR Syrian Arab Republic, UAE United Arab Emirates The following formula was used to calculate an adjustment index (Al): Al $=[$ Total number of publications for the country / GDP per capita of the country] $\times 1000$ where GDP per capita is the country's GDP divided by its population

The most commonly used terms and collaboration between countries were recognized by using the VOSviewer bibliometric software (version 1.6.16) [46], which made it possible to view the measured variables on scientific maps. The maps or clusters were generated by the union of terms or countries that have some connection between them, creating individual clusters and distinguished by similar colours. In term clusters, a frame labels each word. The frame size reflects the number of publications in the collection of selected papers for the term. Therefore, we decided to produce and visualize the network terms that were used in the title/abstract of publications to identify hot topics in this field.

\section{Results}

The total number of COVID-19-related publications obtained by using COVID-19-related terms as a topic in the Scopus search engine (Title/Abstract/Keywords) without stating the name of any country was 143,975 publications, reflecting the overall global COVID-19 research output. Just 6131 (4.26\% of the total global COVID-19 research output) publications were collected from the Arab countries using the methodology mentioned above: 3990 (65.08\%) original journal articles, 980 (15.98\%) review articles, 514 (8.38\%) letters and 647 $(10.55 \%)$ others, such as editorials or notes.

The country-by-country publication review found that the highest number of COVID-19 publications was published by Saudi Arabia ( $n=2186,35.65 \%)$, followed by Egypt $(n=1281,20.78 \%)$ and the United Arab Emirates (UAE) $(n=719,11.73 \%)$. In Table 1 , the list of Arab countries is shown, ordered by AI based on the GDP per capita. Saudi Arabia is ranked first in both production and AI in these results. The UAE, Lebanon and Kuwait come in second, third and fourth, respectively. Lebanon and Yemen, on the other hand, rank third and seventh, respectively, according to the AI which are considered as lower GDP per capita than the other nations.

In addition, 3135 (51.13\%) publications from collaborations with 138 non-Arab countries were recognized by the analysis. Table 2 shows the collaboration between Arab countries and the top 20 non-Arab countries in the research on COVID-19. These collaborations were mostly with researchers from the USA $(n=968,15.79 \%)$, followed by the UK $(n=661,10.78 \%)$, India $(n=550,8.79 \%)$, Pakistan $(n=363,5.92 \%)$ and Italy $(n=341,5.56 \%)$. 
Table 2 Collaboration between Arab countries and top 20 nonArab countries in research on COVID-19

\begin{tabular}{llll}
\hline Ranking & Country & Number of publication & $\%$ \\
\hline 1st & United States & 968 & 15.79 \\
2nd & United Kingdom & 661 & 10.78 \\
3rd & India & 550 & 8.97 \\
4th & Pakistan & 363 & 5.92 \\
5th & Italy & 341 & 5.56 \\
6th & Canada & 319 & 5.20 \\
7th & China & 306 & 4.99 \\
8th & Australia & 272 & 4.44 \\
9th & France & 250 & 4.08 \\
10th & Germany & 209 & 3.41 \\
10th & Malaysia & 209 & 3.41 \\
12th & Spain & 189 & 3.08 \\
13th & Turkey & 174 & 2.84 \\
13th & Iran & 160 & 2.61 \\
15th & Switzerland & 150 & 2.45 \\
16th & South Africa & 148 & 2.41 \\
17th & Brazil & 138 & 2.25 \\
18th & Japan & 129 & 2.10 \\
18th & Netherlands & 129 & 2.10 \\
20th & South Korea & 116 & 1.89 \\
\hline
\end{tabular}

Figure 1 illustrates a visualization network of cooperation between Arab countries and also between Arab and non-Arab countries, created using the VOSviewer visualization software. The USA and the UK are at the centre of cooperation and have the most substantial collaboration with Arab countries.

A total of 25,562 institutions contributed to 6131 publications on COVID-19. Table 3 shows the top ten institutions with the largest number of publications on COVID-19 from Arab countries. The King Saud University ( $n=429$ publications) ranked first, followed by King Abdulaziz University ( $n=308$ publications) and Cairo University ( $n=278$ publications). In addition, Saudi Arabia accounted for four of the top ten institutions, indicating that the country has many outstanding research groups in this area.

The ten most influential peer-reviewed journals are presented in Table 4, representing approximately $8.45 \%$ of the total journals publishing scientific research in this field. The International Journal of Environmental Research and Public Health (1.16\%), the Pan African Medical Journal (1.04\%) and the Journal of Biomolecular Structure and Dynamics $(0.91 \%)$ were ranked as the top three most influential journals, with 71, 64 and 56 publications, respectively. In the top ten productive journals the number of publications is not high, accounting for just $8.45 \%$ of all publications, which indicates that a wide variety of mainstream journals are available, providing more resources for the large research interest in this area.

The research history of COVID-19 is short but dynamic. A total of 25,193 citations were obtained from publications on COVID-19. The $h$-index was 64 and, on

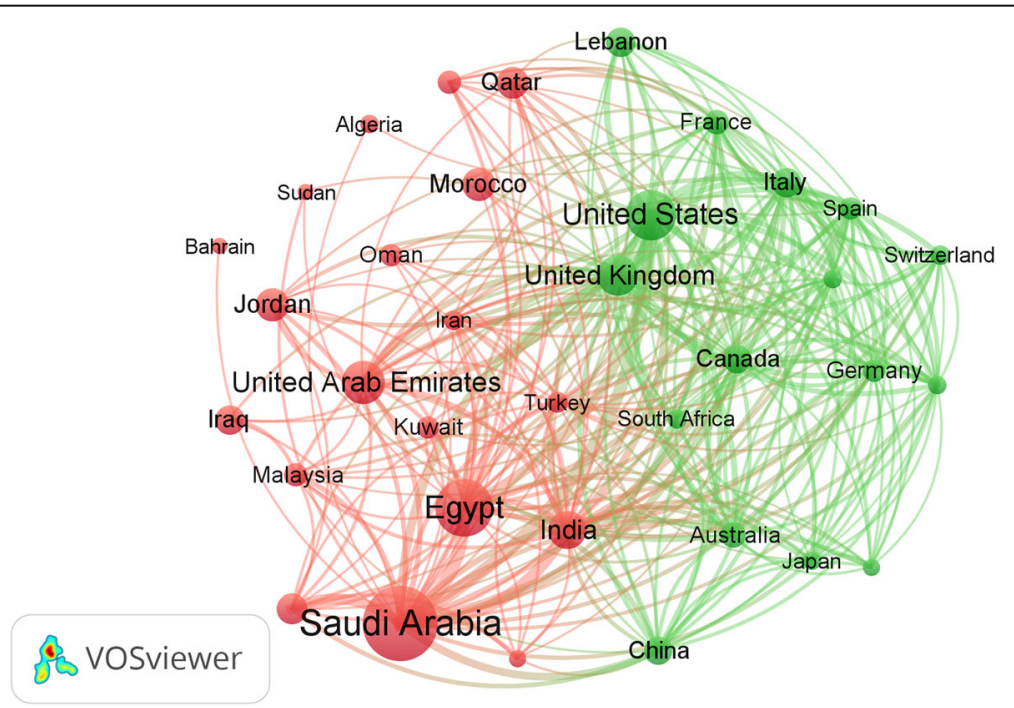

Fig. 1 Network visualization map of Arab international research collaboration among countries with minimum research output of 100 documents on COVID-19-related publications from the Arab world. The map was created using VOSviewer software version 1.6.16 
Table 3 The top ten rankings of productive institutions from Arab countries

\begin{tabular}{llll}
\hline Ranking & Institution & Country & $\boldsymbol{n}$ \\
\hline 1st & King Saud University & Saudi Arabia & 429 \\
2nd & King Abdulaziz University & Saudi Arabia & 308 \\
3rd & Cairo University & Egypt & 278 \\
4th & King Saud bin Abdulaziz University for Health Sciences & Saudi Arabia & 1.02 \\
5th & Imam Abdulrahman Bin Faisal university & Saudi Arabia & 151 \\
6th & Hamad Medical Corporation & Qatar & 142 \\
7th & Qatar University & Qatar & 140 \\
8th & University of Sharjah & United Arab Emirates & 136 \\
9th & Jordan University of Science and Technology & Jordan & 132 \\
10th & American University of Beirut & Lebanon & 130 \\
\hline
\end{tabular}

average, each paper earned 4.11 citations. Table 5 shows the top 20 most cited articles in the field of COVID-19, with the citation counts ranging from 138 to 940 [47-66].

Hot research topics in COVID-19 publications from the Arab world have been presented in network visualization by mapping more than 50 times the cooccurrence of terms in the Title/Abstract in Scopus database publications (Fig. 2). A total of 342 out of the 88,868 terms reached the threshold and this set of terms was scattered into four different clusters (Fig. 2). The highest cluster (Cluster 1: red colour) contains 123 terms that refer mainly to public health and epidemiology, such as "perception", "education", "knowledge", "survey", "student", "experience" and "practice". Cluster 2 (green colour) involves 91 terms related to viruses, including immunological and pharmaceutical research, such as "ACE2", "replication", "receptor", "binding", "cytokine", "therapy", "clinical trial", "vaccine", "drug" and "interaction". Cluster 3 (blue colour) involves 73 terms related to signs, symptoms and clinical diagnoses, such as "fever", "sign", "admission", "case report", "comorbidity", "mortality", "acute respiratory distress syndrome" and "diagnosis". Finally, Cluster 4 (yellow colour) includes 55 terms related to virus detection, such as "detection", "prediction", "model", "diagnosis", "sensitivity" and "specificity".

\section{Discussion}

Bibliometric studies provide interesting methods for measuring the scientific value of a particular field over a specific time. This study mapped Arab research in COVID-19 during the early phase of the epidemic. The findings show that research collaboration is overwhelmingly spread between high-income countries/regions and Arab countries.

However, only the top three countries in the Arab world - Saudi Arabia, Egypt and the UAE - ranked worldwide in terms of the number of COVID-19 research publications: 17th, 33rd and 44th, respectively. In the Arab world, the number of publications remains remarkably lower than in the rest of the world, despite much improvement in COVID-19. The bulk of publications often come from a small number of countries (i.e. Saudi Arabia, Egypt and the UAE) and institutions within these countries.

Table 4 The top ten rankings of journals publishing COVID-19-related publications from the Arab world

\begin{tabular}{|c|c|c|c|c|}
\hline Ranking & Journal & $n$ & $\%$ & IF \\
\hline $1 s t$ & International Journal of Environmental Research and Public Health & 71 & 1.16 & 2.849 \\
\hline 2nd & Pan African Medical Journal & 64 & 1.04 & NA \\
\hline $3 \mathrm{rd}$ & Journal of Biomolecular Structure and Dynamics & 56 & 0.91 & 3.301 \\
\hline 4 th & Plos One & 55 & 0.90 & 2.740 \\
\hline 5 th & International Journal of Infectious Diseases & 47 & 0.77 & 3.202 \\
\hline 5 th & Results in Physics & 47 & 0.77 & 4.019 \\
\hline 7th & Frontiers in Public Health & 46 & 0.75 & 2.483 \\
\hline 8th & Medical Hypotheses & 45 & 0.73 & 1.375 \\
\hline 9th & Journal of Infection and Public Health & 44 & 0.72 & 2.447 \\
\hline 10th & Chaos Solitons snd Fractals & 43 & 0.70 & 3.764 \\
\hline
\end{tabular}

IF is the impact factor for 2019 journals listed in Incites Journal Citation Reports, Clarivate Analytics 
Table 5 The 20 most cited articles in the area of COVID-19 in Scopus from the Arab world

\begin{tabular}{|c|c|c|c|c|}
\hline Ranking & Authors & Year & Source title & Cited by \\
\hline $1 s t$ & Hui et al. [47] & 2020 & International Journal of Infectious Diseases & 940 \\
\hline 2nd & Rodriguez-Morales et al. [48] & 2020 & Travel Medicine and Infectious Disease & 642 \\
\hline $3 r d$ & Chu et al. [49] & 2020 & The Lancet & 538 \\
\hline 4 th & Alhazzani et al. [50] & 2020 & Intensive Care Medicine & 534 \\
\hline 5 th & Bedford et al. [51] & 2020 & The Lancet & 380 \\
\hline 6 th & Phua et al. [52] & 2020 & The Lancet Respiratory Medicine & 375 \\
\hline 7th & COVIDSurg Collaborative [53] & 2020 & The Lancet & 285 \\
\hline 8th & Petrosillo et al. [54] & 2020 & Clinical Microbiology and Infection & 259 \\
\hline 9th & Elfiky [55] & 2020 & Life Sciences & 227 \\
\hline 10th & Xu et al. [56] & 2020 & Viruses & 217 \\
\hline 11th & Tahir ul Qamar et al. [57] & 2020 & Journal of Pharmaceutical Analysis & 215 \\
\hline 12th & Elfiky [58] & 2020 & Life Sciences & 213 \\
\hline 12th & Alhazzani et al. [59] & 2020 & Critical Care Medicine & 213 \\
\hline 14th & Al-Shamsi et al. [60] & 2020 & Oncologist & 177 \\
\hline 15th & Khailany et al. [61] & 2020 & Gene Reports & 149 \\
\hline 16th & Rabi et al. [62] & 2020 & Pathogens & 147 \\
\hline 17th & Meo et al. [63] & 2020 & European Review for Medical and Pharmacological Sciences & 146 \\
\hline 18th & Zumla et al. [64] & 2020 & The Lancet & 141 \\
\hline 19th & Bastard et al. [65] & 2020 & Science & 138 \\
\hline 19th & Ashour et al. [66] & 2020 & Pathogens & 138 \\
\hline
\end{tabular}

These findings tend to be compatible with other health research systems in the Arab world that have previously been identified in various health areas, such as breast cancer research [67], complementary medicine research [68], dengue research [17], infectious disease research [69], leishmaniasis research [70], mental health research [71], pharmaceutical wastewater research [72], road traffic injuries [73], tobacco smoking research [74] and toxicology research [75]. In general, in recent decades, the amount of medical research conducted in the Arab world has increased dramatically but is still relatively low compared to other countries in the world [76]. Lack of sufficient scientific infrastructure and services, lack of resources, political instability in Arab countries and difficulty publishing in high-impact journals are reasons for this shortcoming [77-80]. With regard to COVID-19 publications, the open access policy introduced by many publishers has theoretically led to the accelerated distribution of information and the explosive growth of publications over a short time [25].

A large amount of meaningful data can be obtained from the study of term co-occurrence, allowing hotspots and patterns to be identified and directing researchers to relevant topics in their field $[81,82]$. Therefore, the main research lines identified in COVID-19 from the Arab world in the current study are related to: public health and epidemiology; immunological and pharmaceutical research; signs, symptoms and clinical diagnosis; and virus detection. Previous studies at the global level [11, $31,32]$ have shown the same findings in research directions, in line with the current results. A global bibliometric analysis of COVID-19 conducted by Deng et al. [11] found that four research areas covered the principal topics of public health, clinical and pharmaceutical research and preventive medicine and epidemiology. Zyoud and Al-Jabi [32] performed another global bibliometric review of COVID-19. They shed fresh light on the main progress of hot research topics on COVID-19, including studies of clinical characteristics, pathological findings, therapeutic design, planning of care facilities and infection control. In fact, Arab countries, like many others, have been highly collaborative in science, hitting $50.9 \%$ for COVID-19, which is a potential reason for this similarity between Arab countries and the global level. Continuing and improving future collaboration between developing and developed countries will also help to facilitate the sharing of responsibilities for COVID-19 in research results and the implementation of policies for COVID-19.

The article with the highest total citations $(n=940)$ was published by Hui et al. [47] in the International Journal of Infectious Diseases as an editorial and concluded that the exchange of knowledge and learning from all geographical regions and across disciplines 


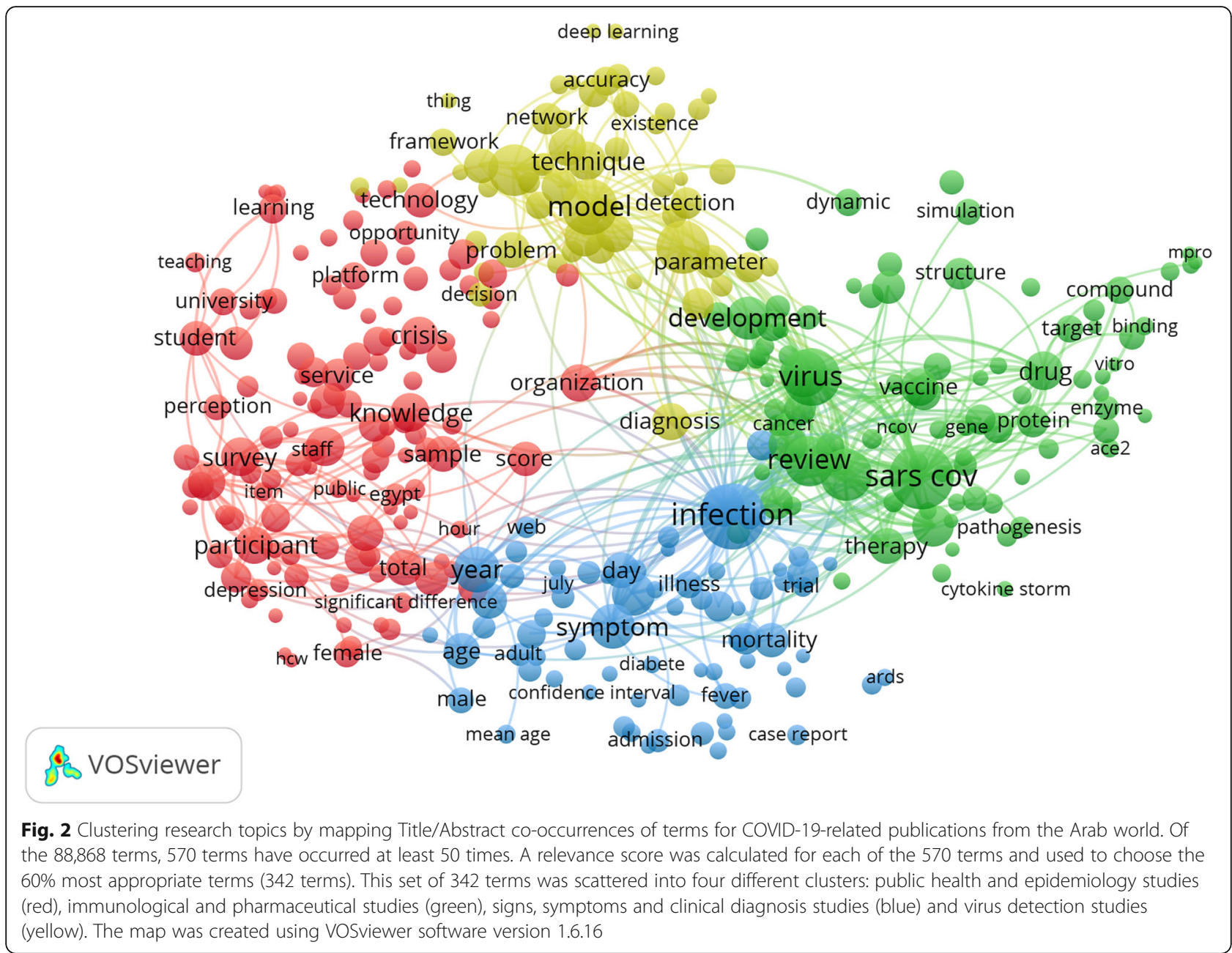

would be necessary to maintain and further improve development. The second top-cited article was published in Travel Medicine and Infectious Disease as a systematic review and meta-analysis [48] and concluded that because this coronavirus has spread globally, human resources, infrastructure and facilities need to be prepared urgently for each country to treat extreme COVID-19 cases. In addition, the third top-cited article was published in The Lancet as a systematic review and metaanalysis [49] and recommended that protection is strongly correlated with physical distances of at least 1 $\mathrm{m}$ apart but distances of up to $2 \mathrm{~m}$ may be more efficient. Furthermore, the fourth top-cited article was published in Intensive Care Medicine as a guideline [50] and found that 54 statements were released by the Surviving Sepsis Campaign COVID-19 panel (including 4 best practice statements, 9 strong recommendations and 35 poor recommendations). In addition, the research highlighted in the most widely cited publications introduces the main current hot topics in the current study [47-66], which offers a substantial and valuable perspective on growing publications and hot topics in this field that motivate research development over time. The top-cited articles' essential contribution is that it would be necessary to exchange knowledge and to learn from all geographical areas and across disciplines to maintain and further improve the progress achieved.

\section{Strengths and limitations}

To the best of our knowledge, this study was the first to conduct a bibliometric analysis of the documentary records of COVID-19-related research during the early phase of the epidemic by using VOSviewer to assess the current hot topics of Arab world research based on COVID-19. The present bibliometric analysis has some limitations and constraints. For instance, because the Scopus database is considered the most accurate and comprehensive database of publications and citations, PubMed and Web of Science were not included in the analyses. No search query is $100 \%$ perfect and there is always a chance for false positives and false negatives [83]: databases such as PubMed, EMBASE, Web of 
Science, Google Scholar and Dimension may give different sets of records for searching but a comparison is beyond the scope of bibliometric analysis in the current study. In our research, the ranking of institutions presented was based on the data given by Scopus. The names of institutions may vary in spelling in some instances, which could generate an inaccuracy in these institutions' recorded productivity. In addition, owing to the brief amount of time after the pandemic initiation and the continually shifting existence of COVID-19 research, the number of citations will vary with time.

\section{Conclusions}

The following conclusions are drawn based on the findings of this bibliometric research: (1) countries such as Saudi Arabia and Egypt, considering the skills of Saudi and Egyptian scientists in this area, can lead Arab researchers in this field; (2) with the global upsurge in COVID-19 study, substantial collaborations have been established between countries or regions, among which the USA and the UK are at the centre of cooperation and have the strongest relations of cooperation with Arab countries; and (3) In the current analysis, the key research lines found in COVID-19 from the Arab world are related to: public health and epidemiology; immunological and pharmaceutical research; signs, symptoms and clinical diagnosis; and virus detection. The outcomes of the current study will enable researchers, academics, clinicians and government leaders from the Arab world to enhance efficiency in future studies and understand further applications in the area of COVID19. In particular, understanding the evolution of the emerging scientific knowledge on COVID-19 is beneficial not just to the scientific community but also to evidence-based policy-making to fully resolve the COVID-19 pandemic's implications. To introduce and carry out research on COVID-19, researchers in lowand middle-income countries such as the Arab world must develop collaborations and connections with researchers in high-income countries.

\section{Abbreviations}

Al: Adjustment index; COVID-19: Coronavirus disease 2019; GDP: Gross domestic product; UAE: United Arab Emirates; WHO: Orld Health Organization

\section{Acknowledgements}

The author would like to thank An-Najah National University for all administrative assistance during the project's implementation.

\section{Author's contributions}

S.Z., the sole author, read and approved the final manuscript.

\section{Funding}

No support for conducting this study was received.

\section{Availability of data and materials}

All data generated or analysed during this study are included in this published article. Other datasets used during the current study are available from the author on reasonable request (saedzyoud@yahoo.com).

\section{Declarations}

Ethics approval and consent to participate

As this is a bibliometric study, without human involvement, there was no need for ethical approval.

Consent for publication

Not applicable.

\section{Competing interests}

The author declares that he has no competing interests.

Received: 26 February 2021 Accepted: 18 March 2021

Published online: 25 March 2021

\section{References}

1. Zhou F, Yu T, Du R, Fan G, Liu Y, Liu Z, et al. Clinical course and risk factors for mortality of adult inpatients with COVID-19 in Wuhan, China: a retrospective cohort study. Lancet. 2020;395(10229):1054-62. https://doi. org/10.1016/S0140-6736(20)30566-3.

2. Shi H, Han X, Jiang N, Cao Y, Alwalid O, Gu J, et al. Radiological findings from 81 patients with COVID-19 pneumonia in Wuhan, China: a descriptive study. Lancet Infect Dis. 2020;20(4):425-34. https://doi.org/10.1016/S1473-3 099(20)30086-4.

3. Dong E, Du H, Gardner L. An interactive web-based dashboard to track COVID-19 in real time. Lancet Infect Dis. 2020;20(5):533-4. https://doi.org/1 0.1016/S1473-3099(20)30120-1.

4. Mofijur M, Fattah IMR, Alam MA, Islam A, Ong HC, Rahman SMA, et al. Impact of COVID-19 on the social, economic, environmental and energy domains: lessons learnt from a global pandemic. Sustain Prod Consum. 2021:26:343-59. https://doi.org/10.1016/j.spc.2020.10.016.

5. World Health Organization. Coronavirus disease (COVID-19) outbreak situation. 2021. https://www.who.int/emergencies/diseases/novel-corona virus-2019 (accessed March 9 2021)

6. Al-Kindi KM, Alkharusi A, Alshukaili D, Al Nasiri N, Al-Awadhi T, Charabi Y, et al. Spatiotemporal assessment of COVID-19 spread over Oman using GIS techniques. Earth Syst Environ. 2020;4(4):797-811. https://doi.org/10.1007/ s41748-020-00194-2.

7. Grasselli G, Zangrillo A, Zanella A, Antonelli M, Cabrini L, Castelli A, et al. Baseline characteristics and outcomes of 1591 patients infected with SARSCoV-2 admitted to ICUs of the Lombardy region, Italy. JAMA. 2020;323(16): 1574-81. https://doi.org/10.1001/jama.2020.5394.

8. Park JJH, Decloedt EH, Rayner CR, Cotton M, Mills EJ. Clinical trials of disease stages in COVID 19: complicated and often misinterpreted. Lancet Glob Health. 2020;8(10):e1249-50. https://doi.org/10.1016/S2214-109X(20)30365-X.

9. Wang J, Hong N. The COVID-19 research landscape: measuring topics and collaborations using scientific literature. Medicine (Baltimore). 2020;99(43): e22849. https://doi.org/10.1097/MD.0000000000022849.

10. Dehghanbanadaki H, Seif F, Vahidi Y, Razi F, Hashemi E, Khoshmirsafa M, et al. Bibliometric analysis of global scientific research on coronavirus (COVID-19). Med J Islam Repub Iran. 2020;34:51. https://doi.org/10.34171/ mjiri.34.51.

11. Deng Z, Chen J, Wang T. Bibliometric and visualization analysis of human coronaviruses: prospects and implications for COVID-19 research. Front Cell Infect Microbiol. 2020;10:581404. https://doi.org/10.3389/fcimb.2020.581404.

12. Fan J, Gao Y, Zhao N, Dai R, Zhang H, Feng X, et al. Bibliometric analysis on COVID-19: a comparison of research between English and Chinese studies. Front Public Health. 2020;8:477. https://doi.org/10.3389/fpubh.2020.00477.

13. Gianola S, Jesus TS, Bargeri S, Castellini G. Characteristics of academic publications, preprints, and registered clinical trials on the COVID-19 pandemic. PLoS One. 2020;15(10):e0240123. https://doi.org/10.1371/journal. pone.0240123.

14. Liu N, Chee ML, Niu C, Pek PP, Siddiqui FJ, Ansah JP, et al. Coronavirus disease 2019 (COVID-19): an evidence map of medical literature. BMC Med Res Methodol. 2020;20(1):177. https://doi.org/10.1186/s12874-020-01059-y. 
15. National Library of Medicine. COVID-19 is an emerging, rapidly evolving situation: SARS-CoV-2 Data. 2021. https://www.ncbi.nlm.nih.gov/sars-cov-2/ (accessed March 8 2021).

16. Al-Jabi SW. Global research trends in West Nile virus from 1943 to 2016: a bibliometric analysis. Glob Health. 2017;13(1):55. https://doi.org/10.1186/s12 992-017-0284-y.

17. Zyoud SH. Dengue research: a bibliometric analysis of worldwide and Arab publications during 1872-2015. Virol J. 2016;13(1):78. https://doi.org/10.1186/ s12985-016-0534-2

18. Zyoud SH. Global research trends of Middle East respiratory syndrome coronavirus: a bibliometric analysis. BMC Infect Dis. 2016;16(1):255. https:// doi.org/10.1186/s12879-016-1600-5.

19. Almeida-Guerrero A, Olaya-Gómez JC, Sánchez-Ramírez N, Murillo-García DR, Cardona-Ospina JA, Lagos-Grisales GJ, et al. Mitigation of the global impact of Lassa fever: have we investigated enough about this Arenavirus? - a bibliometric analysis of Lassa fever research. Travel Med Infect Dis. 2018;24: 13-4. https://doi.org/10.1016/j.tmaid.2018.06.012.

20. Del Carpio OL. Guillain-Barré syndrome associated with zika virus infection in the Americas: a bibliometric study. Neurologia. 2020;35(6):426-9. https:// doi.org/10.1016/j.nrl.2018.05.001.

21. Okoroiwu HU, López-Muñoz F, Povedano-Montero FJ. Bibliometric analysis of global Lassa fever research (1970-2017): a 47 - year study. BMC Infect Dis. 2018;18(1):639. https://doi.org/10.1186/s12879-018-3526-6.

22. Rios-González CM, Verón Mellid FG. When has it been studied about La Crosse virus?: Bibliometric analysis of world scientific production. J Infect Public Health. 2018;11(5):745-6. https://doi.org/10.1016/j.jiph.2017.07.003.

23. Sweileh WM. Global research output on HIV/AIDS-related medication adherence from 1980 to 2017. BMC Health Serv Res. 2018;18(1):765. https:// doi.org/10.1186/s12913-018-3568-X.

24. Zou Y, Luo Y, Zhang J, Xia N, Tan G, Huang C. Bibliometric analysis of oncolytic virus research, 2000 to 2018. Medicine (Baltimore). 2019;98(35): e16817. https://doi.org/10.1097/MD.0000000000016817.

25. ElHawary H, Salimi A, Diab N, Smith L. Bibliometric analysis of early COVID19 research: the top 50 cited papers. Infect Dis (Auckl). 2020;13: 1178633720962935. https://doi.org/10.1177/1178633720962935.

26. Gong Y, Ma TC, Xu YY, Yang R, Gao LJ, Wu SH, et al. Early research on COVID-19: a bibliometric analysis. Innovation (N Y). 2020;1(2):100027. https:// doi.org/10.1016/j.xinn.2020.100027.

27. Klingelhofer D, Braun M, Bruggmann D, Groneberg DA. Coronavirus: an insight into global research until outbreak of COVID-19 and its implications for the future. J Glob Health. 2020;10(2):020508. https://doi.org/10.7189/jogh.10.020508.

28. Martinez-Perez C, Alvarez-Peregrina C, Villa-Collar C, Sanchez-Tena MA. Citation network analysis of the novel coronavirus disease 2019 (COVID-19). Int J Environ Res Public Health. 2020;17(20):7690. https://doi.org/10.3390/ ijerph17207690.

29. Mohadab ME, Bouikhalene B, Safi S. Bibliometric method for mapping the state of the art of scientific production in Covid-19. Chaos, Solitons Fractals. 2020;139:110052. https://doi.org/10.1016/j.chaos.2020.110052.

30. Yang F, Zhang S, Wang Q, Zhang Q, Han J, Wang L, et al. Analysis of the global situation of COVID-19 research based on bibliometrics. Health Inf Sci Syst. 2020;8(1):30. https://doi.org/10.1007/s13755-020-00120-w.

31. Yu Y, Li Y, Zhang Z, Gu Z, Zhong H, Zha Q, et al. A bibliometric analysis using VOSviewer of publications on COVID-19. Ann Transl Med. 2020;8(13): 816. https://doi.org/10.21037/atm-20-4235.

32. Zyoud SH, Al-Jabi SW. Mapping the situation of research on coronavirus disease-19 (COVID-19): a preliminary bibliometric analysis during the early stage of the outbreak. BMC Infect Dis. 2020;20(1):561. https://doi.org/10.11 86/s12879-020-05293-z.

33. Zyoud SH, Zyoud AH. Coronavirus disease-19 in environmental fields: a bibliometric and visualization mapping analysis. Environ Dev Sustain. 2020. https://doi.org/10.1007/s10668-020-01004-5.

34. Yang $\mathrm{KL}$, Jin XY, Gao Y, Xie J, Liu M, Zhang JH, et al. Bibliometric analysis of researches on traditional Chinese medicine for coronavirus disease 2019 (COVID-19). Integr Med Res. 2020;9(3):100490. https://doi.org/10.1016/j.imr.2 020.100490

35. Verma S, Gustafsson A. Investigating the emerging COVID-19 research trends in the field of business and management: a bibliometric analysis approach. J Bus Res. 2020;118:253-61. https://doi.org/10.1016/j.jbusres.2020.06.057.

36. Falagas ME, Pitsouni El, Malietzis GA, Pappas G. Comparison of PubMed, Scopus, web of science, and Google scholar: strengths and weaknesses. FASEB J. 2008;22(2):338-42. https://doi.org/10.1096/fj.07-9492LSF.
37. Kulkarni AV, Aziz B, Shams I, Busse JW. Comparisons of citations in web of science, Scopus, and Google scholar for articles published in general medical journals. JAMA. 2009;302(10):1092-6. https://doi.org/10.1001/jama.2 009.1307.

38. Mongeon P, Paul-Hus A. The journal coverage of web of science and Scopus: a comparative analysis. Scientometrics. 2015;106(1):213-28. https:// doi.org/10.1007/s11192-015-1765-5.

39. Felice FDE, Polimeni A. Coronavirus Disease (COVID-19): A Machine Learning Bibliometric Analysis. In Vivo. 2020;34(3 Suppl):1613-7. https://doi.org/10.21 873/invivo.11951.

40. Furstenau LB, Rabaioli B, Sott MK, Cossul D, Bender MS, Farina E, et al. A Bibliometric Network Analysis of Coronavirus during the First Eight Months of COVID-19 in 2020. Int J Environ Res Public Health. 2021:18(3):952. https:// doi.org/10.3390/ijerph18030952.

41. Zyoud SH, Al-Jabi SW, Sweileh WM, Al-Khalil S, Zyoud SH, Sawalha AF, et al. The Arab world's contribution to solid waste literature: a bibliometric analysis. J Occup Med Toxicol. 2015;10(1):35. https://doi.org/10.1186/s12995015-0078-1.

42. World Bank Group. Countries and Economies 2019. 2020. https://data. worldbank.org/country (accessed March 8 2021).

43. Zyoud SH. Bibliometric analysis on global Catha edulis (khat) research production during the period of 1952-2014. Glob Health. 2015;11(1):39. https://doi.org/10.1186/s12992-015-0124-x.

44. Zyoud SH. Estimates of global research productivity in using nicotine replacement therapy for tobacco cessation: a bibliometric study. Glob Health. 2018;14(1):14. https://doi.org/10.1186/s12992-018-0335-z.

45. Zyoud SH, Waring WS, Sweileh WM, Al-Jabi SW. Global research trends in Lithium toxicity from 1913 to 2015: a Bibliometric analysis. Basic Clin Pharmacol Toxicol. 2017;121(1):67-73. https://doi.org/10.1111/bcpt.12755.

46. van Eck NJ, Waltman L. Software survey: VOSviewer, a computer program for bibliometric mapping. Scientometrics. 2010;84(2):523-38. https://doi. org/10.1007/s11192-009-0146-3.

47. Hui DS, IA E, Madani TA, Ntoumi F, Kock R, Dar O, et al. The continuing 2019-nCoV epidemic threat of novel coronaviruses to global health - the latest 2019 novel coronavirus outbreak in Wuhan, China. Int J Infect Dis. 2020:91:264-6. https://doi.org/10.1016/j.ijid.2020.01.009.

48. Rodriguez-Morales AJ, Cardona-Ospina JA, Gutiérrez-Ocampo E, Villamizar-Peña R, Holguin-Rivera Y, Escalera-Antezana JP, et al. Clinical, laboratory and imaging features of COVID-19: a systematic review and meta-analysis. Travel Med Infect Dis. 2020;34:101623. https://doi.org/10.1 016/j.tmaid.2020.101623.

49. Chu DK, Akl EA, Duda S, Solo K, Yaacoub S, Schünemann HJ. Physical distancing, face masks, and eye protection to prevent person-to-person transmission of SARS-CoV-2 and COVID-19: a systematic review and metaanalysis. Lancet. 2020;395(10242):1973-87. https://doi.org/10.1016/S0140-673 6(20)31142-9.

50. Alhazzani W, Moller MH, Arabi YM, Loeb M, Gong MN, Fan E, et al. Surviving Sepsis campaign: guidelines on the management of critically ill adults with coronavirus disease 2019 (COVID-19). Intensive Care Med. 2020:46(5):854-87. https://doi.org/10.1007/s00134-020-06022-5.

51. Bedford J, Enria D, Giesecke J, Heymann DL, Ihekweazu C, Kobinger G, et al. COVID-19: towards controlling of a pandemic. Lancet. 2020;395(10229): 1015-8. https://doi.org/10.1016/S0140-6736(20)30673-5.

52. Phua J, Weng L, Ling L, Egi M, Lim CM, Divatia JV, et al. Intensive care management of coronavirus disease 2019 (COVID-19): challenges and recommendations. Lancet Respir Med. 2020;8(5):506-17. https://doi.org/10.1 016/S2213-2600(20)30161-2.

53. COVIDSurg Collaborative. Mortality and pulmonary complications in patients undergoing surgery with perioperative SARS-CoV-2 infection: an international cohort study. Lancet. 2020;396(10243):27-38. https://doi.org/1 0.1016/S0140-6736(20)31182-X.

54. Petrosillo N, Viceconte G, Ergonul O, Ippolito G, Petersen E. COVID-19, SARS and MERS: are they closely related? Clin Microbiol Infect. 2020;26(6):729-34. https://doi.org/10.1016/j.cmi.2020.03.026.

55. Elfiky AA. Anti-HCV, nucleotide inhibitors, repurposing against COVID-19. Life Sci. 2020;248:117477. https://doi.org/10.1016/j.lfs.2020.117477.

56. Xu J, Zhao S, Teng T, Abdalla AE, Zhu W, Xie L, et al. Systematic comparison of two animal-to-human transmitted human Coronaviruses: SARS-CoV-2 and SARS-CoV. Viruses. 2020;12(2):244. https://doi.org/10.3390/v12020244.

57. Tahir UI Qamar M, Alqahtani SM, Alamri MA, Chen LL. Structural basis of SARS-CoV-2 3CL(pro) and anti-COVID-19 drug discovery from 
medicinal plants. J Pharm Anal. 2020;10(4):313-9. https://doi.org/10.101 6/j.jpha.2020.03.009.

58. Elfiky AA. Ribavirin, Remdesivir, Sofosbuvir, Galidesivir, and Tenofovir against SARS-CoV-2 RNA dependent RNA polymerase (RdRp): a molecular docking study. Life Sci. 2020;253:117592. https://doi.org/10.1016/.lfs.2020.117592.

59. Alhazzani W, Møller MH, Arabi YM, Loeb M, Gong MN, Fan E, et al. Surviving Sepsis campaign: guidelines on the Management of Critically ill Adults with coronavirus disease 2019 (COVID-19). Crit Care Med. 2020;48(6):e440-69. https://doi.org/10.1097/CCM.0000000000004363.

60. Al-Shamsi HO, Alhazzani W, Alhuraiji A, Coomes EA, Chemaly RF, Almuhanna $\mathrm{M}$, et al. A practical approach to the Management of Cancer Patients during the novel coronavirus disease 2019 (COVID-19) pandemic: an international collaborative group. Oncologist. 2020;25(6):e936-45. https:// doi.org/10.1634/theoncologist.2020-0213.

61. Khailany RA, Safdar M, Ozaslan M. Genomic characterization of a novel SARS-CoV-2. Gene Rep. 2020;19:100682. https://doi.org/10.1016/j.genrep.202 0.100682 .

62. Rabi FA, Al Zoubi MS, Kasasbeh GA, Salameh DM, Al-Nasser AD. SARS-CoV-2 and coronavirus disease 2019: what we know so far. Pathogens. 2020;9(3): 231. https://doi.org/10.3390/pathogens9030231.

63. Meo SA, Alhowikan AM, Al-Khlaiwi T, Meo IM, Halepoto DM, Iqbal M, et al. Novel coronavirus 2019-nCoV: prevalence, biological and clinical characteristics comparison with SARS-CoV and MERS-CoV. Eur Rev Med Pharmacol Sci. 2020;24(4):2012-9. https://doi.org/10.26355/eurrev_202 002 20379.

64. Zumla A, Hui DS, Azhar El, Memish ZA, Maeurer M. Reducing mortality from 2019-nCoV: host-directed therapies should be an option. Lancet. 2020; 395(10224):e35-6. https://doi.org/10.1016/S0140-6736(20)30305-6.

65. Bastard P, Rosen LB, Zhang Q, Michailidis E, Hoffmann HH, Zhang Y, et al. Autoantibodies against type I IFNs in patients with life-threatening COVID-19. Science. 2020;370(6515):eabd4585. https://doi.org/10.1126/science.abd4585.

66. Ashour HM, Elkhatib WF, Rahman MM, Elshabrawy HA. Insights into the Recent 2019 Novel coronavirus (SARS-CoV-2) in light of past human coronavirus outbreaks. Pathogens. 2020;9(3):186. https://doi.org/10.3390/pa thogens 9030186

67. Sweileh WM, Zyoud SH, Al-Jabi SW, Sawalha AF. Contribution of Arab countries to breast cancer research: comparison with non-Arab middle eastern countries. BMC Womens Health. 2015;15(1):25. https://doi.org/10.11 86/s12905-015-0184-3.

68. Zyoud SH, Al-Jabi SW, Sweileh WM. Scientific publications from Arab world in leading journals of integrative and complementary medicine: a bibliometric analysis. BMC Complement Altern Med. 2015;15(1):308. https:// doi.org/10.1186/s12906-015-0840-z.

69. Sweileh WM, Al-Jabi SW, Abuzanat A, Sawalha AF, AbuTaha AS, Ghanim MA, et al. Assessment of research productivity of Arab countries in the field of infectious diseases using web of science database. Infect Dis Poverty. 2015; 4(1):2. https://doi.org/10.1186/2049-9957-4-2.

70. Al-Jabi SW. Arab world's growing contribution to global leishmaniasis research (1998-2017): a bibliometric study. BMC Public Health. 2019;19(1): 625. https://doi.org/10.1186/s12889-019-6969-9.

71. Zeinoun P, AkI EA, Maalouf FT, Meho LI. The Arab Region's contribution to global mental Health Research (2009-2018): a Bibliometric analysis. Front Psychiatry. 2020;11:182. https://doi.org/10.3389/fpsyt.2020.00182.

72. Zyoud SH, Zyoud SH, Al-Jabi SW, Sweileh WM, Awang R. Contribution of Arab countries to pharmaceutical wastewater literature: a bibliometric and comparative analysis of research output. Ann Occup Environ Med. 2016; 28(1):28. https://doi.org/10.1186/s40557-016-0117-0.

73. Butt FM, Ashiq M, Rehman SU, Minhas KS, Ajmal Khan M. Bibliometric analysis of road traffic injuries research in the Gulf Cooperation Council region. F1000Res. 2020;9:1155. https://doi.org/10.12688/f1000research.2 5903.2.

74. Zyoud SH, Al-Jabi SW, Sweileh WM, Awang R. A Scopus-based examination of tobacco use publications in middle eastern Arab countries during the period 2003-2012. Harm Reduct J. 2014;11(1):14. https://doi.org/10.1186/14 77-7517-11-14.

75. Zyoud SH, Al-Jabi SW, Sweileh WM, Awang R. A bibliometric analysis of toxicology research productivity in Middle Eastern Arab countries during a 10-year period (2003-2012). Health Res Policy Syst. 2014;12:4. https://doi. org/10.1186/1478-4505-12-4.

76. Jones AC, Geneau R. Assessing research activity on priority interventions for non-communicable disease prevention in low- and middle-income countries: a bibliometric analysis. Glob Health Action. 2012;5:1-13. https:// doi.org/10.3402/gha.v5i0.18847

77. El-Azami-El-Idrissi M, Lakhdar-Idrissi M, Ouldim K, Bono W, Amarti-Riffi A, Hida M, et al. Improving medical research in the Arab world. Lancet. 2013; 382(9910):2066-7. https://doi.org/10.1016/S0140-6736(13)62692-6.

78. Sibai AM, Singh NV, Jabbour S, Saleh S, Abdulrahim S, Naja F, et al. Does published research on non-communicable disease (NCD) in Arab countries reflect NCD disease burden? PLoS One. 2017;12(6):e0178401. https://doi. org/10.1371/journal.pone.0178401.

79. Nakkash R, Afifi R, Maziak W. Research and activism for tobacco control in the Arab world. Lancet. 2014;383(9915):392-3. https://doi.org/10.1016/S014 $0-6736(13) 62381-8$

80. El Rassi R, Meho LI, Nahlawi A, Salameh JS, Bazarbachi A, Akl EA. Medical research productivity in the Arab countries: 2007-2016 bibliometric analysis. J Glob Health. 2018;8(2):020411. https://doi.org/10.7189/jogh.08.020411.

81. Su H-N, Lee P-C. Mapping knowledge structure by keyword co-occurrence: a first look at journal papers in technology foresight. Scientometrics. 2010; 85(1):65-79. https://doi.org/10.1007/s11192-010-0259-8.

82. Jia Q, Shi S, Yuan G, Shi J, Shi S, Hu Y. Analysis of knowledge bases and research hotspots of coronavirus from the perspective of mapping knowledge domain. Medicine (Baltimore). 2020;99(22):e20378. https://doi. org/10.1097/MD.0000000000020378.

83. Sweileh WM, Al-Jabi SW, AbuTaha AS, Zyoud SH, Anayah FMA, Sawalha AF. Bibliometric analysis of worldwide scientific literature in mobile - health: 2006-2016. BMC Med Inform Decis Mak. 2017;17(1):72. https://doi.org/10.11 86/s12911-017-0476-7.

\section{Publisher's Note}

Springer Nature remains neutral with regard to jurisdictional claims in published maps and institutional affiliations.

Ready to submit your research? Choose BMC and benefit from:

- fast, convenient online submission

- thorough peer review by experienced researchers in your field

- rapid publication on acceptance

- support for research data, including large and complex data types

- gold Open Access which fosters wider collaboration and increased citations

- maximum visibility for your research: over $100 \mathrm{M}$ website views per year

At $\mathrm{BMC}$, research is always in progress.

Learn more biomedcentral.com/submissions 